PROBLEMS

OF MANAGEMENT IN THE $21^{\text {st }}$ CENTURY Vol. 11, No. 1, 2016

\section{6}

\title{
DEVELOPMENT OF PUBLIC TRANSPORT: FUTURE CHALLENGES OF LIEPAJA`S TRAM (LATVIA)
}

Diāna Līduma, Aija Kairēna, Inese Lūsēna-Ezera

Liepaja University, Liepaja, Latvia

E-mail: diana_liduma@inbox.Iv, aija.kairena@liepu.Iv, inese.lusena-ezera@liepu.lv

Monta Šimkus

SIA Liepājas tramvajs, Liepaja, Latvia

E-mail: simkus.monta@gmail.com

\begin{abstract}
Transport has always had an important role in the lifestyle of population and development of economy, but the public transport performs mainly the social function - it works for the benefit of the society. Development and quality of services must be provided also for the public transport companies, however, we meet different problems related to infrastructure and traffic for this to happen. To successfully manage and develop a public transport company, it is essential to change the thinking of people in favour of the public transport, not for the personal transport. It is necessary to ensure the sustainability as the main value, which means selection of the right public transport system.

The authors relied on the experience of formation of a unified transport system in the world and Latvia's largest cities'strategic vision for public transport development.

Taking into account the fact that Liepaja is one the three cities in Latvia where the public transport service is provided by a tram, an empiric research was made. Its aim was to clarify the opinion of the inhabitants of Liepaja, regarding the services provided by Liepaja trams, regarding the possible improvements and necessity for development.

200 inhabitants of Liepaja were questioned within the framework of the research. The results of the research revealed that although the tram provides daily the inhabitants of Liepaja with the movement possibilities, unfortunately inhabitants are not ready yet to replace their personal transport with the public transport-tram to settle their daily problems. The results of the research allowed to conclude that future development possibilities and perspectives of the tram in Liepaja City can be related mainly with the creation of a new route, purchase of new carriages and unified public transport system in Liepaja City.

Key words: availability and sustainability, Liepaja tram, public transport, social function of public transport.
\end{abstract}

\section{Introduction}

Transport is one of the strategically most important areas of economy in every country. It ensures continuous flows of freight and mobility of persons. Influence of transport economics in the national economy is stated by its proportion in the gross domestic product that according to the data of Central Statistical Bureau makes on average 10\% of GDP annually in Latvia. In the national economic growth it is related directly with the transportation of freight, but in the economics of cities the public transport system is of importance where the public 
transport performs mainly the social function. According to L. Glover: "there is an opinion that the public transport must be supported because it ensures social welfare or the welfare of individual segments of the society, therewith, it means that the public transport exists and works for the benefit of the society" (Glover, 2011, 1). The social role of the public transport is emphasised also by Rachel Kyte, the vice president of the World Bank, stating that from the social point of view, the public transport is often the only available transport for poor people, and without the public transport the poor people would have to find the job near their homes, at such distances that they could manage on foot. R. Kyte is convinced that the public transport improves their livelihood opportunities; it ensures not only the economic active inhabitants, but also pensioners, disabled persons and children with wider access to education, healthcare and recreation, not only (Kyte, 2015). Also, the Latvian transport development planning document "Guidelines for Transport Development 2014 - 2020" emphasises the social function of the public transport in Latvia - to satisfy the demand of population for the public transport services irrespective of their income and to ensure the possibility to attend educational establishments, medical institutions, workplaces, state and municipal institutions during their normal (generally accepted) working hours in the route networks (Matīss, 2013).

With the increase of economic activity, the public transport is to be supported also in the context of environment quality, considering not only the issue of availability, but also the importance of regulation of traffic intensity, environmental load and reduction of pollution, by choosing a more environmentally friendly traffic arrangement in the result of what the following questions become topical: what kind of movement and transport choose the people? To what extent do they use the public transport? Can it replace the usage of the private transport? Is it possible to get positive support from the inhabitants in the formation of an environmentally friendly traffic? Already fifteen years ago N. Sprancmanis, professor at Riga Technical University, stated that practically all forms of transport are used in transportation of passengers depending on the length of drive, taste of passengers, their ability to pay and urgency of traffic, however the main factor for increase of vehicles is passenger cars - traffic hassle has increased in the cities, traffic speed has reduced in the centre of the city, problems with parking places have emerged, the number of collisions and pollution of city environment with gasses and noise has increased. (Sprancmanis, 2001, 254 - 256). The increase of topicality of the mentioned problems is confirmed also by individual practical research. For example, within the framework of research "Regarding the attitude of citizens of European Union Member States towards the movement" made by the European Commission and the research company TNS Barometer during the period from 24 May to 9 June 2013, by inquiring 27680 citizens of European Union aged from 18 to 74 years in 28 Member States, has obtained data that confirm the problems and present the situation in the scale of Latvia and other European countries: inhabitants of Latvia mention the transport costs $(74 \%)$, accidents $(62 \%)$, air pollution $(58 \%)$, traffic jams $(53 \%)$ and noise $(45 \%)$ as important problems in the cities. For comparison - on average air pollution $(81 \%)$ is named as the most important problem in cities among the European Union Member States. The trend that the car is still the dominant means of transport in the cities - on average $76 \%$ of the respondents go by car at least once a week on average in EU (in Latvia this indicator is a bit lower $-65 \%$ of respondents) - was confirmed. Inhabitants of Latvia are also active walkers $-97 \%$ of Latvian citizens go on foot at least once a week, that is the highest indicator among all EU Member States (88\% Europeans on average at least once a week go on foot), and the inhabitants of Latvia use also actively the public transport - almost half or $49 \%$ of inhabitants use it at least once a week. This indicator ranks the citizens of Latvia as the most active users of the public transport among all 28 EU Member States, because on average one third (35\%) Europeans at least once a week use the public transport (Lāce, 2013).

In parallel to the issue of the social function of the public transport and the environmental load, the aspect of sustainable public transport system is also outlined. As the researcher V. Sarma notes, the sustainability is often understood only in the context of ecology, however it should be understood as interaction of social, economic and environmental factors, because 
Diāna LİDUMA, Aija KAIRĒNA, Inese LŪSĒNA-EZERA, Monta ŠIMKUS. Development of public transport: Future challenges of Liepaja`s tram (Latvia)

OF MANAGEMENT

N THE $21^{\text {st }}$ CENTURY Vol. 11, No. 1, 2016

18

nowadays it is impossible to separate these concepts (Sarma, 2012). As most of the authors state in the theory (Kḷavina, Anča, etc.), the irrespective of the field of activity, a balanced sum of social sphere, environmental and economic factors perspective is searched in the future when planning a balanced development and such balance can be searched objectively also in the formation of the public transport system by facilitating a population-friendly movement opportunity. R. Kyte has a similar opinion by emphasising the necessity to choose the correct public transport system and underlining the importance of sustainability linking it with the availability of balanced transport system to passengers and the long-term economic viability of the service (Kyte, 2015). Approaches of sustainability value of transport sphere in world's and European level anticipate that "the inhabitants must be provided with an opportunity to choose freely the form of transport to carry freights or passengers; all inhabitants must be provided with the social contacts, respectively transport of passengers; traffic safety must be improved; correct proportion between the charge for transport and quality of transport must be ensured (transport of passengers should be divided in three classes - the most prosperous inhabitants use the first class, but the poor inhabitants use the third class transport), therewith the inhabitants would have a possibility to choose according to their material opportunities; comfort, cleanness and auxiliary rooms of appropriate quality must be ensured; full responsibility of transport regarding the quality of traffic, appropriate speed of traffic and regularity must be ensured." (Sprancmanis, 2011, 156 - 157). Most of the mentioned principles are anticipated also in the Latvian transport system. As the expected result it is stated in the vision formulated in the Latvian sustainable transport system "Guidelines for Transport development 2014-2020" - available public transport that ensures reachability within the whole territory of Latvia (convenient, unified public transport system, attaining mutual consistency of bus and railway transport) (Matīss, 2013).

Tram is not only an environmentally friendly means of transport, but it is also one of the fastest types of the public transport (it has traffic arrangement advantages, it is not disturbed by traffic jams). An important fact in the context of environmental load is that the public transport can carry a larger number of passengers at the same time. Authors of the research note that, for example, the low-floor tram $15 \mathrm{~T}$ can carry maximum 318 passengers at the same time (Riga Traffic, n.d.). The following speaks in favour of tram development as the type of the public transport: "the width and arrangement of motor roads with rapid increase of number of cars on the main motorways is determined by economic restrictions related with huge costs of road construction or extension. This circumstance limits the dynamics by anticipating in perspective the necessity to increase another, replacing means of transport, mainly railway development in freight and passenger transport within and outside the city" (Sprancmanis, 2011, 151).

Tram as one of the forms of public transport is implemented in three largest cities of Latvia: Riga, Daugavpils and Liepaja. At present the fastest tram in Latvia (the average speed reaches $17,25 \mathrm{~km} / \mathrm{h}$ ) and the oldest electric tram line in the Baltic States is located in Liepaja. In Liepaja there is one tram line that is $14.8 \mathrm{~km} \operatorname{lng}$, in comparison in Daugavpils there are 3 tram routes (JSC Daugavpils satiksme, 2014), but in Riga - 9 (the total length of rail road $124 \mathrm{~km}$, but the average speed $16.07 \mathrm{~km} / \mathrm{h}$ ). ("Rìgas satiksme" has announced ..., 2015). Data of Central Statistical Bureau of the Republic of Latvia regarding the dynamics of tram passengers in Riga, Daugavpils and Liepaja from 2011-2014 testify that the total fall of number of tram passengers in Latvia was observed in 2012, but when comparing the indicators for 2012, 2013 and 2014, we can see an increase of the number of passengers (Table 1). In 2013 the construction of the new tram line was completed and in the section of annual data of the Central Statistical Bureau it is reflected in the increase of number of passengers in 2014 (Table 1). 
Table 1. Transportation dynamics of tram passengers in Latvia in section of cities 2011-2014, thou. passengers (Central Statistical Bureau, 2015).

\author{
PROBLEMS \\ OF MANAGEMENT \\ IN THE $21^{\text {st }}$ CENTURY \\ Vol. 11 , No. 1, 2016
}

\begin{tabular}{lllll}
\hline & Liepäja & Rìga & Daugavpils & Total \\
\hline 2011 & 2877 & 32051 & 6661 & 41589 \\
\hline 2012 & 2777 & 30695 & 7112 & 40584 \\
\hline 2013 & 3166 & 33752 & 7336 & 44254 \\
\hline
\end{tabular}

The authors note that the total number of passengers depends, of course, on the number of inhabitants in the particular city, however the common trends testify that the availability of transport can also facilitate usage thereof.

When there are different types of public transport, it is important that inhabitants have a choice in favour of a particular type of transport, observing the strategically important purpose of the public transport system - sustainability and promotion of usage of environmentally friendly public transport system in the urban environment. On the base of future vision of Liepaja Tram "to improve and develop availability and quality of an environmentally friendly public transport", the authors see a necessity for a practical research regarding this strategically important issue, assessing the availability of trams in the urban environment and determining future challenges of Liepaja Tram in the joint public transport system.

\title{
Methodology of Research
}

\section{General Background of Research}

"Public transport solutions are an important challenge for the city transport. Such type of transport serves not only as the precondition for an acceptable standard of living, but shows also the strategical resource to maintain the competitiveness in the city. Concurrently with the growth of cities, it is necessary to develop further the principle organizations and transport systems." (Volvo research and educational foundations, n.d.). For example, Riga Public Transport Development Concept 2005-2018 prescribes that "the aim of development of public transport in city traffic is to ensure a qualitative alternative of the means of transport for all social groups of inhabitants that can compete with the passenger cars. Public transport has a crucial role in provision of mobility of inhabitants in the conditions of the ever increasing automobilization and consequently in the decreasing quality of the surrounding environment. It is necessary to ensure a modal division of application of the types of means of transport in favour of the public transport by developing and implementing appropriate long-term development strategies." (Riga Public Transport Development Concept, 2005). The main qualitative indicators of the public transport prescribed in the concept are: "availability and offer that meets the demand; speed, safety and comfort; integrated system of all types of public transports, incl. ticket; information system of passengers that corresponds with the modern technologies." (Riga Public Transport Development Concept, 2005). But the aim of Liepaja City is to attain a safe and convenient traffic in the city by developing a long-term transport movement plan, by carrying out a reconstruction target program of the existing streets and implementing the project "Safe traffic in Liepaja". To improve the mobility of inhabitants, availability of public transport must be improved in the city, including the availability of electric transport (tram), cycle routes and bike parking places must be built and the pedestrian areas must be extended, that gives also the ecological benefit to the city and enables the development of ecotourism. It is important to encourage the inhabitants of the city to wave the usage of motor transport in the traffic of the city. To improve the safety of the traffic in the city, the council improves different 
Diāna LĪDUMA, Aija KAIRĒNA, Inese LŪSĒNA-EZERA, Monta ŠIMKUS. Development of public transport: Future challenges of Liepaja`s tram (Latvia)

$\begin{array}{r}\text { OF MANAGEMENT } \\ \text { IN THE } 21^{\text {st }} \text { CENTURY } \\ \text { Vol. 11, No. 1, 2016 } \\ \hline 20\end{array}$

1

types of informative, preventive and educational events regarding the safety of traffic (Liepaja City Council, 2007). The topicality of the mentioned problems of urban environment in the development of transport system is considered at world and European, national and regional level, arriving to the intentions of particular populated places and cities to solve them.

To assess the services provided by the tram as a type of public transport in Liepaja City, to assess its advantages and clarify the possible development directions of the tram, inhabitants of Liepaja City were questioned within the framework of the research.

\section{Instrument and Procedure}

The questionnaire consists of 13 questions, including 3 demographical questions. The structure of the questions is formed mainly by the closed questions. The required selection (192 inhabitants) was calculated by means of the random selection method and on the base data for 2013, regarding the population in Liepaja City (in total 8 residential districts), separately observing the age structure from 15-78 years. The selection of inhabitants was made in Liepaja City, by dividing it in two blocks: the first block comprised those residential districts of Liepaja City, where the tram doesn't run (Karosta, Tosmare, Zạıā birze and Ziemelı Suburb), the second block - those residential districts, where the tram runs (South-West district, Ezerkrasts, New Liepaja and Old Liepaja). The average indicator was calculated for the purpose of intercomparison - the aim in each of eight residential districts of Liepaja City was to obtain 24 filled in questionnaires. To ensure the required amount of selection and assuming that some of the questionnaires is invalid, one additional questionnaire was added in each residential district, thus increasing the planned amount of selection of Liepaja population. The questioned inhabitants are quite young - the average age is 32 years. The employment status of respondents: more than half $(58.5 \%)$ of the respondents are salaried workers, $22 \%$ are pupils/students. Tram as a type of public transport is used by $58.5 \%(\mathrm{n}=117)$ of questioned inhabitants of Liepaja City.

\section{Results of Research}

SIA "Liepājas tramvajs" is one of the components of Liepaja City Municipal Agency "Liepaja Public Transport" that was created in June 2011. SIA "Liepājas tramvajs" is a capital company that is owned $100 \%$ by Liepaja Municipality and that ensures one of the forms of the public transport in Liepaja. SIA "Liepājas tramvajs" is a company with broad history that is rich with changes and important stages in its development starting already with 1984 when negotiations were commenced, regarding the introduction of electricity and tram in Liepaja City. (Liepājas tramvajs, 2015) The total length of tram route in Liepaja City is currently 14.8 kilometres. The whole route in one direction takes on average 30 minutes with 18 stops in each direction. Liepaja tram line is serviced by Tatra KT4 trams that can be seen also only in Tallinn, Estonia.

After having clarified the opinion of Liepaja inhabitants $(n=117$, the respondents who use the services of a tram) regarding the regularity of usage of Liepaja tram as a public transport in Liepaja City, it can be concluded that although most frequently the tram is used by those inhabitants whose residential districts are crossed by the tram route (inhabitants of New Liepaja district $-53 \%$ and inhabitants of South-West district of which $26 \%$ go by tram daily or use it at least 2-3 times a week $-47 \%$ ), in individual cases the tram is used also by inhabitants of those residential districts where the tram doesn't go, for example, $80 \%$ of inhabitants of Tosmare go by tram 1-2 times a month. The results testify that also the newly built tram line to Ezerkarsts residential district is used frequently for daily purposes $-15 \%$ of respondents use it daily and $45 \%$ use it $2-3$ times a week. Although the tram line crosses the centre of Old Liepaja, the inhabitants of this district use the services of tram 2-3 times a week (36\%) because the inhabitants can manage the closest distances on foot (Figure 1). 


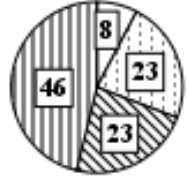

Ziemelu suburb

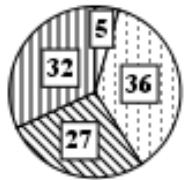

Old Liepaja

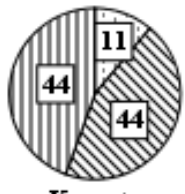

Karosta

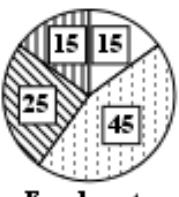

Ezerkrasts

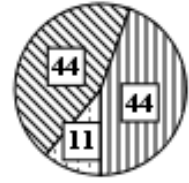

Zaḷa birze

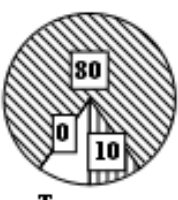

Tosmare

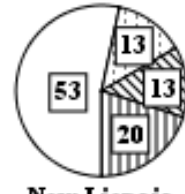

New Liepaja

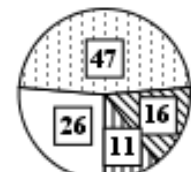

South-West disctric

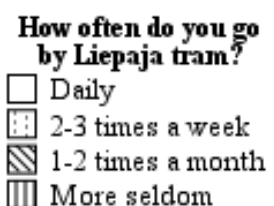

III More seldom
PROBLEMS

OF MANAGEMENT

IN THE $21^{\text {st }}$ CENTURY

Vol. 11, No. 1, 2016

\section{Figure 1: Frequency of usage of Liepaja tram among inhabitants of Liepaja residential districts $(n=117), \%$.}

The results of the research regarding the reasons for use of the tram testify in general, that Liepaja City tram as a type of public transport can provide the previously theoretically emphasises social functions to the inhabitants - the demand of inhabitants for the services of the public transport by ensuring the opportunity to go to the educational establishments, medical institutions, workplaces, state and municipal institutions in the route network. In general, the results state that the questioned inhabitants who use the services of Liepaja tram, use it most frequently for shopping purposes $(21.5 \%)$, arrival to places of entertainment and culture $(15.4 \%)$ and to and from work (14.5\%). When comparing the reasons for using the tram, taking into account the place of residence (residential districts) of Liepaja inhabitants, it can be seen that the tram for work purposes is used more by the inhabitants of South-West (36.4\%) and New Liepaja (24.2\%) districts, but inhabitants of Ezerkrasts (61.5\%) use it mostly to get to the school and home from the school that can be related with the newly built tram line to observe the interests of children and youth in the context of movement mobility within the limits of the city (Table 2). 
Diāna LİDUMA, Aija KAIRĒNA, Inese LŪSĒNA-EZERA, Monta ŠIMKUS. Development of public transport: Future challenges of Liepaja`s tram (Latvia) OF MANAGEMENT
IN THE $21^{\text {st }}$ CENTURY Vol. 11, No. 1, 2016

Table 2. Reasons for using Liepaja tram according to the needs of inhabitants of Liepaja residential districts $(n=117), \%$.

\begin{tabular}{llllllllll}
\hline & $\begin{array}{l}\text { South- } \\
\text { West } \\
\text { district }\end{array}$ & $\begin{array}{l}\text { Ezer- } \\
\text { krasts }\end{array}$ & $\begin{array}{l}\text { New } \\
\text { Liepāja }\end{array}$ & $\begin{array}{l}\text { Ka- } \\
\text { rosta }\end{array}$ & $\begin{array}{l}\text { Tos- } \\
\text { mare }\end{array}$ & $\begin{array}{l}\text { Old } \\
\text { Liepāja }\end{array}$ & $\begin{array}{l}\text { Zalāa } \\
\text { Birze }\end{array}$ & $\begin{array}{l}\text { Ziemelu } \\
\text { Suburb }\end{array}$ & Total \\
\hline $\begin{array}{l}\text { To work and } \\
\text { from work }\end{array}$ & 36.4 & 12.1 & 24.2 & 0 & 3 & 18.2 & 3 & 3 & 14.5 \\
\hline $\begin{array}{l}\text { To school and } \\
\text { from school }\end{array}$ & 7.7 & 61.5 & 15.4 & 0 & 7.7 & 7.7 & 0 & 0 & 5.7 \\
\hline $\begin{array}{l}\text { Going to medi- } \\
\text { cal / social } \\
\text { institution }\end{array}$ & 26.9 & 15.4 & 3.8 & 3.8 & 11.5 & 19.2 & 7.7 & 11 & 11.4 \\
\hline $\begin{array}{l}\text { For entertain- } \\
\text { ment and cul- } \\
\text { ture purposes }\end{array}$ & 25.7 & 22.9 & 8.6 & 8.6 & 0 & 14.3 & 5.7 & 14.3 & 15.4 \\
\hline $\begin{array}{l}\text { For shopping } \\
\text { purposes }\end{array}$ & 16.3 & 20.4 & 16.3 & 4.1 & 10.2 & 12.2 & 10.2 & 10.2 & 21.5 \\
\hline $\begin{array}{l}\text { To visit rela- } \\
\text { tives or friends }\end{array}$ & 10.7 & 25.0 & 14.3 & 10.7 & 7.1 & 17.9 & 3.6 & 10.7 & 12.3 \\
\hline $\begin{array}{l}\text { To get to the } \\
\text { bus terminal }\end{array}$ & 26.9 & 15.4 & 7.7 & 7.7 & 0 & 30.8 & 7.7 & 3.8 & 11.4 \\
\hline
\end{tabular}

After having clarified the opinion of the inhabitants of the city regarding the importance of Liepaja tram, the authors have established that Liepaja tram has not only the role of the social function, but, in the opinion of inhabitants, the tram is an environmentally friendly form of movement, besides with a historic relevance, and it is also as a recognition element of Liepaja as a city. At the same time it is disclosed that from the point of view of traffic arrangement, environment and sustainability, the inhabitants have the opinion that the tram doesn't facilitate largely the movement for other traffic participants, thus decreasing the possibility that personal cars could be replaced with the public transport (Figure 2).

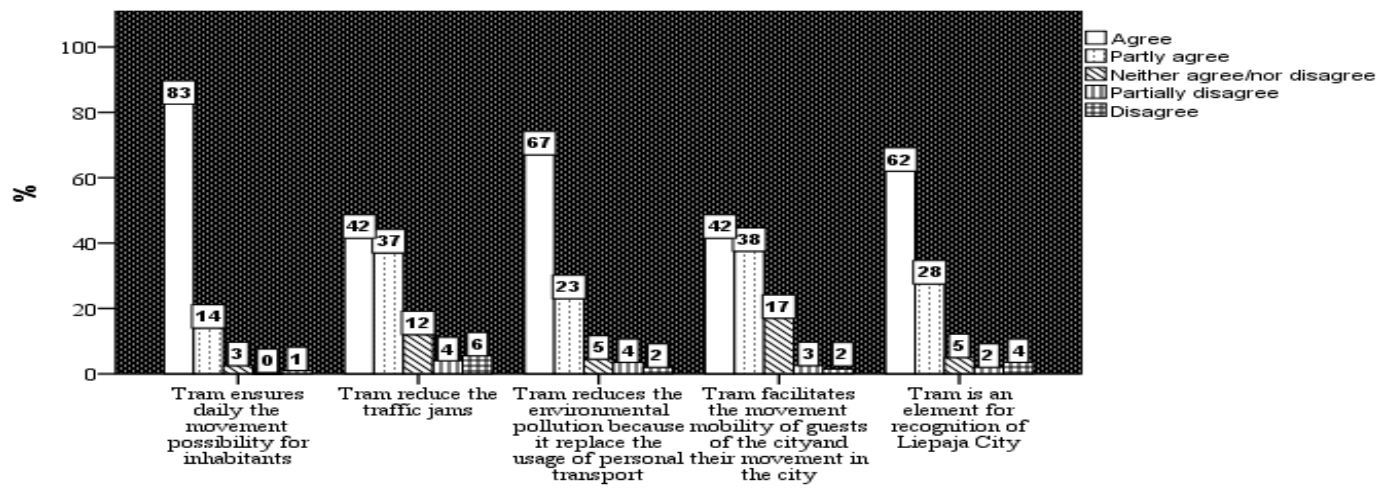

Figure 2: Advantages provided by Liepaja tram in Liepaja City $(n=200)$.

The aforementioned is confirmed by the answers of Liepaja inhabitants to the open question, regarding the advantages of personal transport when compared with the public transport:

- personal car is more convenient (24 respondents); 
- $\quad$ personal car is faster ( 9 respondents);

- with the public transport you cannot get everywhere (9 respondents), incl. 1

PROBLEMS

OF MANAGEMENT

IN THE $21^{\text {st }}$ CENTURY

Vol. 11, No. 1, 2016 respondent has specified that, for example, the tram cannot ensure all required routes.

The following answers speak also for the benefit of the personal transport:

- personal cars have no specific route - no other stops between points A and B;

- public transport fails to comprise districts in so wide scale;

- public transport is not convenient when you have to do the shopping;

- ticket prices are higher than monthly expenses for fuel;

- public transport is expensive and overcrowded;

- personal transport is available 24-hours a day;

- personal car is safer.

Although the advantages of personal transport stated by the questioned inhabitants of Liepaja City testify that comfort, speed and arrival from "door to door" is important for part of the inhabitants, however the opinion whether the usage of the public transport could replace the usage of personal vehicles in future is not so unequivocal: $52 \%$ of respondents have marked such possibility, but the remaining $48 \%$ don't see such an opportunity stating, for example, that the route of tram fails to comprise districts in so wide scale - it's not possible to get everywhere.

When thinking about the improvement of tram services in future, the authors have clarified what improvements, in the opinions of inhabitants, must be introduced (Figure 3). The questioned inhabitants who use the services of the tram $(n=117)$ have stated mostly the necessity to ensure more convenient entrance and exit for parents with prams $(70 \%)$ and for pensioners (49\%) and also to ensure free runs for parents who accompany their children to the age of 5 years $(48 \%)$. At the same time the results of the research state the necessity to improve the internal physical environment of trams, relating it with the creation of more attractive interior (47\%), introduction of climate control (37\%), provision of additional information on current events in Liepaja City (36\%), more convenient placement of chairs (35\%) and playing music (31\%). When compared with the necessity to improve the entrance/exit possibilities in the tram, internal environment of the tram, necessity to improve the driving speed of the tram, the necessity to increase the number of stops and frequency of runs is stated not so often.

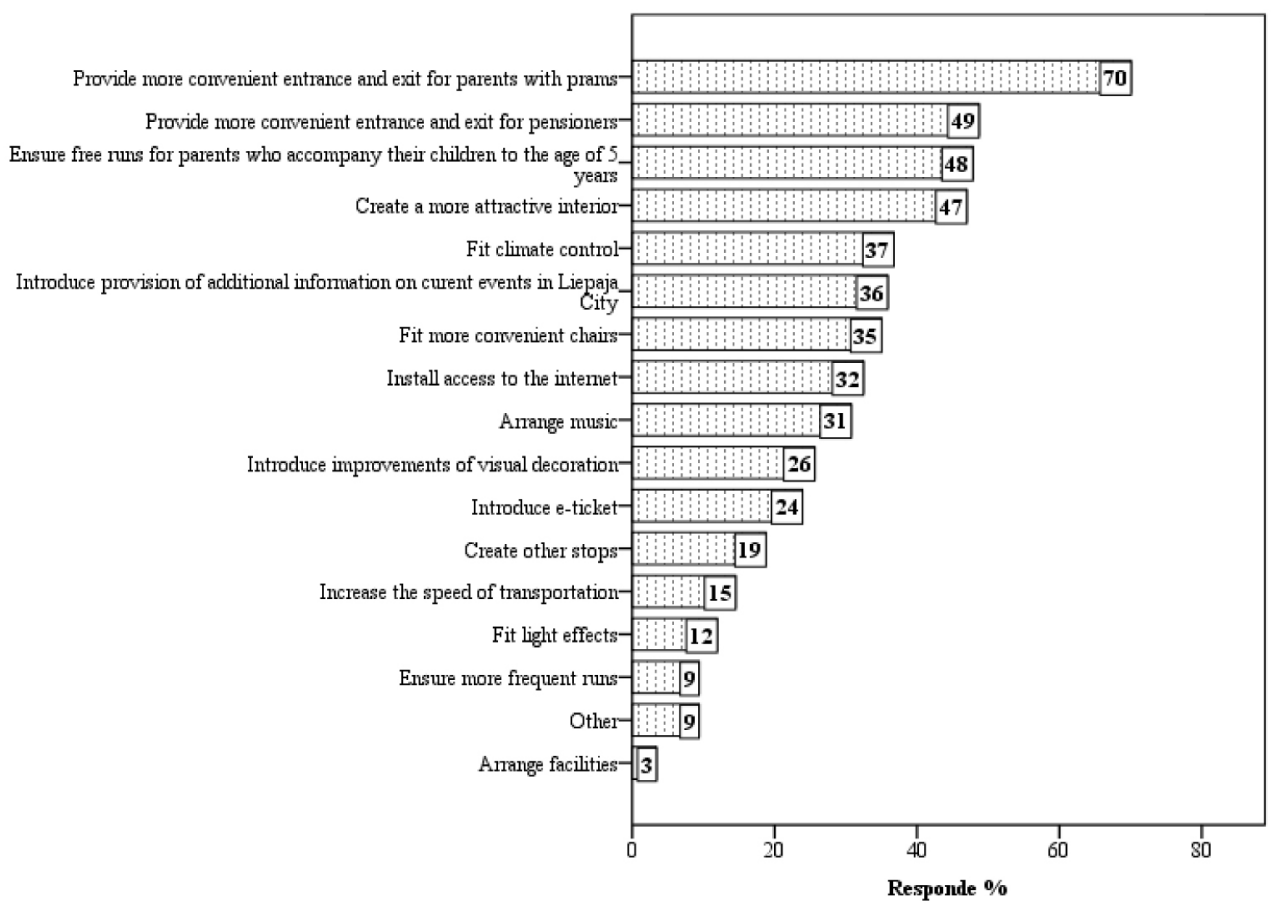

Figure 3: The improvement required in the operation of Liepaja tram $(n=117)$. 
Diāna LĪDUMA, Aija KAIRĒNA, Inese LŪSĒNA-EZERA, Monta ŠIMKUS. Development of public transport: Future challenges of Liepaja`s tram (Latvia)

OF MANAGEMENT N THE $21^{\text {st }}$ CENTURY Vol. 11, No. 1, 2016

As to the total development perspective for this type of public transport, the results reveal that inhabitants of Liepaja City see the route network of Liepaja tram in future with several routes $(62 \%)$, especially emphasising the creation of new tam line to Liepaja Regional Hospital (65\%) (the hospital is near the border of the city) and to Ziemelu suburb (58\%) (a comparatively densely populated residential district). The questioned inhabitants have stated transportation of passengers with the latest, technology-based trams as the second largest future perspective of the tram (43\% (Figure 4$)$, that, in the opinion of the authors, can be related partially with the suggestions in context of improvement of internal environment of the trams made by the questioned tram users and displayed in Figure 3.

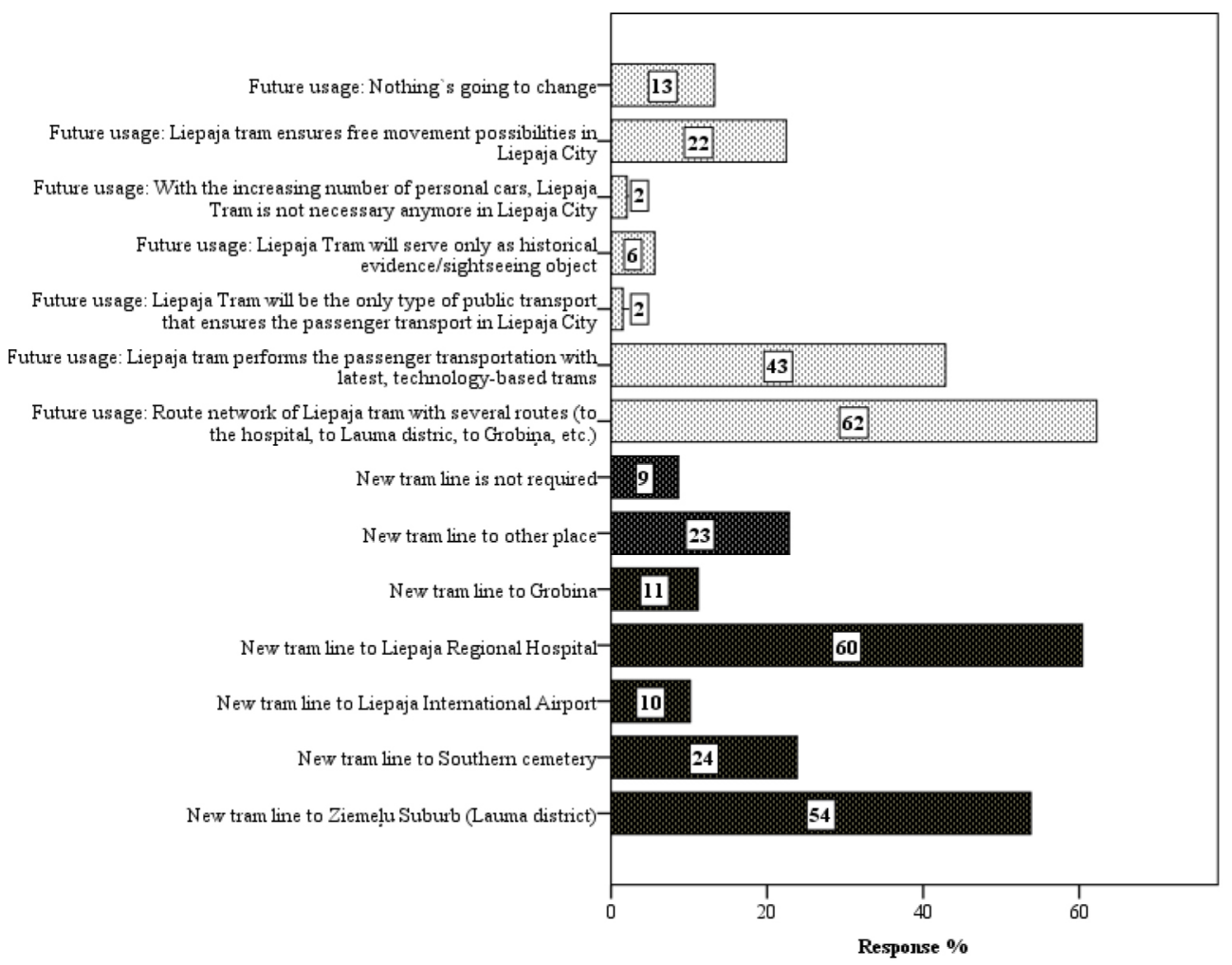

\section{Figure 4: Necessity for new tram lines and tram development perspectives $(n=200)$.}

It can be assumed that if tram routes and other types of public transport in Liepaja would supplement each other thus creating a joint public transport system in Liepaja City, the inhabitants would use more the public transport thus achieving the usage of an environmentally friendly public transport system. As it is stated by the current users of the tram, it needs both convenient technological and economic availability for different social groups. However, the opinion that it is difficult to change the habits of inhabitants so that they use the public transport more frequently instead of the personal transport is also confirmed.

\section{Discussion}

Transport has always had a considerable influence on the lifestyle of people. City passenger transport as the public transport performs mainly the social function and works in the interests of the society. But as to the development of the public transport, the experts state the necessity to ensure sustainability and emphasise the necessity to use the public transport to reduce the traffic problems as the main value. In today's circumstances the pressure from 
government increases regarding the provision of an improved public transport as a sustainable alternative to the personal cars. (Hensher, Ho, Mulley, 2014.) Already for several years there is an opinion that "in the search for solutions to the traffic problems, one of the first is the increase of proportion of the public passenger transport in the city," stated N.Sprancmanis, expert of transport economics, RTU professor (Sprancmanis, 2001, 256). R.Kyte, the vice president of World Bank has a similar opinion: "From the city movement opportunities, the public transport is more efficient that the personal mechanical vehicles in the terms of motor road that it occupies and in the terms of energy that it consumes. Due to the mentioned reasons, the public transport is important to improve the sustainable mobility right in the cities." (Kyte, 2015). In practice it means that the public transport companies need to ensure the development and quality of services, however different infrastructure and traffic arrangement problems are encountered for this to happen. Experts also state that the development of sustainable public transport cannot be ensured only on the account of the existing transport charges, additional financing sources and acquisition of resources is required. To achieve what is intended, it is important to justify the importance of investments in the public transport, by demonstrating such benefits for the society as improved availability, safety and sustainability of transport, at the same time servicing ever increasing number of potential users of the public transport also within the framework of the existing budget (Hensher, Ho, Mulley, 2014). To solve the development issues, from the point of view of the authors, the involved companies and the relevant political forces must be merged.

As the world's experience proves, the public passenger transport system must be combined from different types of public transport. Also, according to the results of the practical research in Liepaja it can be assumed that if several tram routes and other types of public transport within the framework of joint public transport system would supplement each other, the inhabitants would move more by means of the public transport, thus attaining the usage of an environmentally friendly public transport system. As it is stated by the existing users of trams, it needs a convenient technological and economical availability to different social groups. However, the opinion is also approved that it would be hard to change the habits of inhabitants so that they use the public transport instead of their personal transport more frequently.

The authors of the research see 2 possible solutions for this situation:

1) to change the transport system in the urban environment and the provisions for usage thereof. This requires to review the city planning and make different decisions at political level. Referring to experts' researches, different examples for the good practice can be mentioned: "to create borders around a particular part of city centre where private transport is forbidden to go. Such solution is applied in many cities in the world, arranging parking places for the private cars at the particular border and also the traffic of public transport between the parking places and the city centre" (Sprancmanis, 2001, 256). As it is stated by R. Kyte, the transport systems require additionally the integration of several technologies: common ticket or payment card that serves in the whole transport system by facilitating the transfer from one type of the public transport to another; passenger information system so that the users receive instructions when the following public transport arrives at the relevant stop, and the information system on the route in general; provision of frequent services by reducing the problems with waiting time and transportation for available price (Kyte, 2015)

2) to change the opinion of the society in favour of usage of the public transport. To develop successfully a public transport company, the main thing is to achieve changes in the way of persons' thinking in favour of the public transport, not of the personal cars. As it is stated by R. Kyte, strict quality indicators in terms of convenience and reliability must be met where the competition with personal cars cause the greatest problem in the choice of the public transport so that people choose better city public transport instead of their personal cars. (Kyte, 2015) This means that not only the technological and infrastructure solutions must be facilitated in the development of the public transport system, but also the change of public opinion regarding its usage. However, the research results on the usage of Liepaja tram state tendentiously to the disinclination of people to change the habitual situation. 
Diāna LİDUMA, Aija KAIRĒNA, Inese LŪSĒNA-EZERA, Monta ŠIMKUS. Development of public transport: Future challenges of Liepaja`s tram (Latvia)

OF MANAGEMENT

N THE $21^{\text {st }}$ CENTURY Vol. 11, No. 1, 2016

In the opinion of the authors of the research, the motivation of people to choose the private transport is a definite threat and encumbrance for the creation of an environmentally friendly transport system. That is why in the following research answers must be found on the question regarding the more suitable tools for the change of public opinion and habits of people. These are future challenges where solutions must be found in each municipality, this has to be discussed at national and international scale.

\section{Conclusions}

The research confirms the importance of geographical availability of the tram as a public transport and the necessity of it. As the revealed Liepaja tram usage trends state - most frequently the tram is used by those inhabitants of the city whose residential areas are crossed by the tram line. This is certified also by the daily usage of the newly built line. However, if the distances can be easily covered on foot, the inhabitants use the tram more seldom, i.e. 2-3 times a week. In individual cases 1-2 times a month the tram is used by inhabitants of those residential districts, where the tram doesn't go. This is a ground for a research regarding new tram lines to develop the public transport.

The results of the research regarding the reasons for using the tram confirm the importance of the social function of this type of transport that is emphasised in the public transport in general. The results show that the questioned people use the services of Liepaja tram most frequently to ensure the shopping needs, arrive to the places of entertainment and culture, and daily to go to and from work. The last reason is especially topical for the inhabitants of residential districts that are crossed by the tram line. The newly built line in the city has become very important in observance of the interests of children and youth in the context of mobility within the framework of the city - it is used mainly to get to and from school. This confirms the necessity for availability of the tram in the context of different social groups.

After having clarified the opinion of city inhabitants regarding the importance of Liepaja tram, it is concluded that in the opinion of inhabitants, Liepaja tram has not only a role of the social functions, but the tram in general is regarded as an environmentally friendly form of movement, historical relevance and role of recognition of the city is attributed to it. However, from the point of view of traffic arrangement, environment and sustainability, the inhabitants think that the tram fails to facilitate movement for other traffic participants thus reducing the possibility that the personal transport is replaced with the public transport. It is to be concluded that the opinion whether the usage of the public transport could replace the usage of personal vehicles in future is not so unequivocal. It can be assumed that those inhabitants who use already the services of the tram support largely such possibility, but the rest don't see such possibility, pointing to the problem of availability because the tram route fails to comprise the districts of the city in wide enough scale.

Future challenges in the activity of Liepaja tram are:

Creation of tram route networks with several routes - the inhabitants emphasise especially the creation of a new tram line to Liepaja Regional Hospital that is located in the borderland of the city and to Ziemel̦u suburb (a comparatively densely populated residential district).

But to observe the interests of the current users, there is a necessity to ensure more convenient entrance and exit (for parents with prams and for pensioners), and possibility of free movement for parents, who accompany their children to the age of 5 years. The users point to the necessity to improve the internal physical environment of the trams (interior, climate control, provision of additional information regarding the current events in the city, etc.) The necessity to improve the speed of tram, increase the number of stops and frequency of runs is, in the opinion of inhabitants, less important. 
Diāna LİDUMA, Aija KAIRĒNA, Inese LŪSĒNA-EZERA, Monta ŠIMKUS. Development of public transport: Future challenges of Liepaja`s tram (Latvia)

The inquired inhabitants have named the passenger transportation with the latest, technology-based trams as a definite future perspective of the tram that can be partially related with the suggestions of the inquired tram users in the context of improvement of the internal environment of the trams.

\section{References}

„R̄̄gas satiksme” izsludinājusi iepirkumu 20 jaunu zemās grīdas tramvaju iegādei ["Riga Traffic” has announced procurement of 20 new low-floor trams for purchase]. (2015). Retrieved September 14, 2015, from https://www.rigassatiksme.lv/lv/aktualitates/-rigas-satiksme-izsludinajusi-iepirkumu20-jaunu-zemas-gridas-tramvaju-iegadei.

Anča, G., Barisa, L., Cimdinšs, P., Djačkova, S., Dmitrijeva, J., Doškina, I. ... Vorončuka, I. (2002). Tautas attīstība [Human development]. Rīga: Jumava.

Attīstības plānošanas sistēmas likums [Development Planning System Law] 2008 (Parl) (Latv.).

Centrālās statistikas pārvalde. (2015). Pasažieru pārvadājumi [Passenger transportation]. Retvieved from http://data.csb.gov.lv/pxweb/lv/transp/transp__ikgad_transp/TR0270.px/ table/tableViewLayout1/?rxid=cdcb978c-22b0-416a-aacc-aa650d3e2ce0.

Glover, L. (2011). Public Transport as a common pool resource. Retrieved from http://cw.routledge.com/ textbooks/9780415529037/data/4-1-1-Paper.pdf.

Hensher, A. D., Ho, Ch., Mulley, C. (2014). Identifying preferences for public transport investments under a constrained budget. Retrieved from ScienceDirect database.

JSC Daugavpils satiksme (2014). About us. [Fact sheet]. Retvieved from http://satiksme.daugavpils.lv/ par-mums.

Kḷaviņa, M. (2010). Vide un ilgtspējīga attīstība [Environment and sustainable development]. Rīga: LU Akadēmiskais apgāds.

Kyte, R. (2015). A good public transport system must be easy and convenient to use, fast, safe, clean and affordable. Retrieved January 15, 2016, from http://www.global-briefing.org/2012/07/agood-public-transport-system-must-be-easy-and-convenient-to-use-fast-safe-clean-andaffordable/\#auth.

Lāce, A. (2013). Eiropiešu pārvietošanās paradumi pilsētā [Europeans travel behavior in cities]. Retrieved February 16, 2016, from http://www.tns.lv/newsletters/2014/40/?category=tns40\&id=social_ parvietosanas_pilsetas.

Liepājas pilsētas Dome. (2007). Liepājas pilsētas sociāli ekonomiskās attīstības programma 2008.-2014. gadam [Liepaja city socio-economic development program for the period 2008 to 2014th year]. Retvieved from: http://www.liepaja.lv/upload/Bizness/Attistiba/pilsetas/Strategija_GALA_ VERSIJA.pdf.

Liepājas sabiedriskais transports. (2015). About us. [Fact sheet]. Retvieved from http://www. liepajastransports.lv/lv/par-mums.

Liepājas tramvajs. (2015). About us. [Fact sheet]. Retvieved from http://liepajas-tramvajs.lv/lv/parmums/lapa/vesture.

Matīss, A. (2013). Transporta attīstības pamatnostādnes 2014. - 2020. gadam [Transport Development Guidelines for years 2014 - 2020]. Retvieved from http:/www.sam.gov.lv/images/modules/items/ PDF/item_4174_SAMpamn_030713_transp.1pdf.pdf.

Volvo research and e ducational foundations. (n.d.) Public transport development. Retwieved from http://www.vref.se/webbplats20/home/thefutprogramme/researchthemes/ publictransportdevelopment.4.6a462c7912efb9dc 85 f80002387.html.

Rīgas pašvaldības SIA „Rīgas satiksme” ilgtermiņa stratēgija no 2012. gada lìdz 2033. gadam [Riga municipal Ltd. "Riga Traffic" long-term strategy from 2012 to 2033]. (2012). Retvieved from https://www.rigassatiksme.lv/files/rp_sia_rigas_satiksme_strategija_2012_-2033_gadam_1.pdf.

R̄̄gas sabiedriskā transporta attīstības koncepcija 2005.-2018 [Riga public transport development concept for years 2005-2018]. (2005). Retrieved from http://www.rdsd.lv/box/files/ sabiedriskatransportakoncepcija.pdf.

Rīgas satiksme. (n.d.). Retrieved February 16, 2016, from https://www.rigassatiksme.lv/lv/pakalpojumi/ transporta-noma/tramvaji-un-trolejbusi/. 
Diāna LĪDUMA, Aija KAIRĒNA, Inese LŪSĒNA-EZERA, Monta ŠIMKUS. Development of public transport: Future challenges of Liepaja`s tram (Latvia)

OF MANAGEMENT

IN THE $21^{\text {st }}$ CENTURY Vol. 11, No. 1, 2016

28

Sarma, V. (2012). Ilgtspējīgas attīstības izpratnes veidošanās [Forming sustainable development awareness]. Latvijas Architektūra, 102, 96.

SIA „Liepājas tramvajs” darbības un attīstības stratēgija 2014.-2015.gadam [Ltd. „Liepaja tram“ operation and Development Strategy 2014- 2015]. (2014). (Unpublished work, March 29, 2015).

Sprancmanis, N. (2001). Transporta pakalpojumu ekonomika un organizācija [Transport service economy and organization]. Rīga: Rīgas Tehniskā universitāte.

Sprancmanis, N. (2011). Uzņēmējdarbības logistikas pamati [Fundamentals of Business Logistics]. Rīga: Burtene.

Advised by Constantin Bratianu, Academy of Economic Studies, Bucharest, Romania

Received: April 26, 2016

Accepted: June 08, 2016

\begin{tabular}{|ll|}
\hline Diāna Lĩduma & $\begin{array}{l}\text { Mg.oec, Lecturer, Liepaja University, Liela iela 14, Liepaja, LV-3401, Latvia. } \\
\text { E-mail: diana_liduma@inbox.Iv }\end{array}$ \\
\hline Aija Kairēna & $\begin{array}{l}\text { Mg.oec, Lecturer, Liepaja University, Liela iela 14, Liepaja, LV-3401, Latvia. } \\
\text { E-mail: aija.kairena@liepu.Iv }\end{array}$ \\
\hline Inese Lūsēna-Ezera & $\begin{array}{l}\text { Dr.sc.administr., Associate Professor, Liepaja University, Liela iela 14, Liepaja, LV- } \\
\text { 3401, Latvia. } \\
\text { E-mail: inese.lusena-ezera@liepu.lv }\end{array}$ \\
\hline Monta Šimkus & $\begin{array}{l}\text { Bc.oec, Liepaja University, Liela iela 14, Liepaja, LV-3401, Latvia. } \\
\text { E-mail: simkus.monta@gmail.com }\end{array}$
\end{tabular}

